\title{
IL1B, IL4R, IL12RB1 and TNF gene polymorphisms are associated with Plasmodium vivax malaria in Brazil
}

Vinicius A Sortica', Maristela G Cunha ${ }^{3}$, Maria Deise O Ohnishi ${ }^{4}$, Jose M Souza ${ }^{4}$, Ândrea KC Ribeiro-dos-Santos ${ }^{2}$, Ney PC Santos ${ }^{2}$, Sídia M Callegari-Jacques ${ }^{5}$, Sidney EB Santos ${ }^{2}$ and Mara H Hutz ${ }^{*}$

\begin{abstract}
Background: Malaria is among the most prevalent parasitic diseases worldwide. In Brazil, malaria is concentrated in the northern region, where Plasmodium vivax accounts for 85\% disease incidence. The role of genetic factors in host immune system conferring resistance/susceptibility against $P$. vivax infections is still poorly understood.

Methods: The present study investigates the influence of polymorphisms in 18 genes related to the immune system in patients with malaria caused by P. vivax. A total of 263 healthy individuals (control group) and 216 individuals infected by $P$. vivax (malaria group) were genotyped for 33 single nucleotide polymorphisms (SNPs) in IL1B, IL2, IL4, IL4R, IL6, IL8, IL10, IL12A, IL12B, IL12RB1, SP110, TNF, TNFRSF1A, IFNG, IFNGR1, VDR, PTPN22 and P2X7 genes. All subjects were genotyped with 48 ancestry informative insertion-deletion polymorphisms to determine the proportion of African, European and Amerindian ancestry. Only 13 SNPs in 10 genes with differences lower than 20\% between cases and controls in a Poisson Regression model with age as covariate were further investigated with a structured population association test.

Results: The ILIB gene -5839C > T and IL4R 1902A > G polymorphisms and IL12RB1 -1094A/-641C and TNF -1031 T/-863A/-857 T/-308 G/-238 G haplotypes were associated with malaria susceptibility after population structure correction ( $p=0.04, p=0.02, p=0.01$ and $p=0.01$, respectively).

Conclusion: Plasmodium vivax malaria pathophysiology is still poorly understood. The present findings reinforce and increase our understanding about the role of the immune system in malaria susceptibility.
\end{abstract}

Keywords: Malaria, Plasmodium vivax, Immune system polymorphisms, Brazilian amazon, IL 1B, IL4R, IL 12RB1, TNF

\section{Background}

Malaria remains one of the most important parasitic infections in the world with almost 250 million new cases diagnosed annually [1]. It is caused by infection with one or more of five species of Plasmodium parasites. Plasmodium vivax is the second most common cause of malaria in the world after Plasmodium falciparum, with high incidence in Asia, Central and South America causing high morbidity to these populations [2-5]. Traditionally, Brazil has been responsible for almost half of all cases of malaria in Latin America. In 2010,

\footnotetext{
* Correspondence: mara.hutz@ufrgs.br

'Departamento de Genética, Universidade Federal do Rio Grande do Sul, Porto Alegre, RS, Brazil

Full list of author information is available at the end of the article
}

334,618 cases of malaria $(283,384$ caused by $P$. vivax $)$ were reported in this country $[1,6]$.

Plasmodium vivax has unique biological features that distinguish it as a species. The most obvious features that distinguish $P$. vivax from $P$. falciparum include the development of dormant forms (hypnozoites) in the liver that cause subsequent infections in the blood called relapses, which add a substantial number of cases to the general burden of the disease and present one of the most challenging bottlenecks for vivax malaria eradication [7].

A sensitive balance between pro- and anti-inflammatory immune response, primarily mediated by cytokines released by $\mathrm{T}$ helper ( $\mathrm{Th}$ ) cells and macrophages, is necessary for an adequate response to malaria. An early pro-

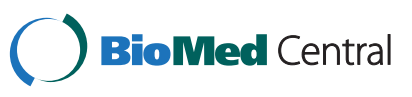


inflammatory response mediated by a set of Th1 cells and macrophages helps to reduce parasitaemia; however, a second anti-inflammatory response mediated by a set of Th2 cells and monocytes is required to control malaria by preventing organ damage and more severe symptoms. Timing and intensity between Th1 and Th2 response and auto-regulation can influence both pathology of infection and its progress [8-10]. Influence of the immune system gene polymorphisms with resistance/susceptibility and severity in $P$. falciparum malaria in Africa and Asia have been reported [11], however the influence of these polymorphisms in $P$. vivax infection is still poorly investigated. In patients with $P$. vivax malaria from India, two single nucleotide polymorphisms (SNP) in the TNF promoter $(-308 \mathrm{G}>\mathrm{A}$ and $-1031 \mathrm{C}>\mathrm{T})$ were associated with tumour necrosis factor (TNF) levels and clinical symptoms but not with susceptibility [12]. A recent work, demonstrated an association of $+874 \mathrm{~A}>\mathrm{T}$ in IFNG gene with Interferon gamma (IFN- $\gamma$ ) plasma levels but not with $-1082 \mathrm{~T}>\mathrm{C}$ in IL10 gene with interleukin (IL) 10 plasma levels in patients infected by $P$. vivax from Brazil [13].

Brazil has a peculiar epidemiological situation, as one of the few countries around the world with $P$. vivax predominance [6]. Data on susceptibility to $P$. vivax infection allied to several particularities of the Brazilian Amazonian region, including the diverse genetic background of its population, indicate that the generalization of findings from Southeast Asia may not be appropriate for this region [6]. The present work aims to investigate the influence of 33 SNPs in genes related to the immune system and susceptibility to P. vivax malaria in an Amazonian population.

\section{Methods \\ Study population}

A total of 216 patients were diagnosed with $P$. vivax malaria at the Evandro Chagas Institute, Belém, Pará between 2002-2009. All patients were diagnosed by thick blood smear as recommended by the Brazilian Ministry of Health [14]. The patients received the standard treatment $1,500 \mathrm{mg}$ of chloroquine associated with $210 \mathrm{mg}$ of primaquine in seven days. Between 2006 and 2008, 263 healthy controls were recruited at the Federal University of Pará. Unrelated subjects were interviewed at the Human and Medical Genetics Laboratory and agreed to donate DNA samples to compose a population sample for genetic studies. The individuals enrolled in the study were born in Pará state in the Brazilian Amazonian region. Patients and controls provided their written informed consent to participate in this study. The Ethics Committees of the Evandro Chagas Institute and Federal University of Pará approved the study protocol.

\section{Genotyping}

Genomic DNA was extracted from peripheral blood leukocyte subjects using proteinase $\mathrm{K}$ digestion and standard phenol-chloroform procedures [15]. All subjects were genotyped for a set of 48 bi-allelic short insertion/deletion (indels) polymorphisms, validated as ancestry informative markers. The genotyping procedure was performed by three multiplex reactions as described elsewhere [16].

The 33 immune system gene SNPs were determined by allelic discrimination with Taqman 5'-nuclease assays. A total of 30 polymorphisms were genotyped with validated genotyping assays (Real Time PCR, Applied Biosystems, CA, USA). Three variants $-174 \mathrm{C}>\mathrm{G}$ (rs1800795), -863A $>\mathrm{C}(\mathrm{rs} 180030)$ and $874 \mathrm{~A}>\mathrm{T}(\mathrm{rs} 2430561)$ were genotyped by custom genotyping assay by design (Applied Biosystems, CA, USA). All assays were genotyped according to the manufacturer's recommended protocol.

\section{Statistical analyses}

Allele and genotype frequencies were estimated by gene counting. Deviation from Hardy-Weinberg equilibrium was assessed by Qui-square tests with Bonferroni correction. Haplotype frequencies and linkage disequilibrium were estimated with PHASE 2.1.1 [17]. Differences between malaria and control samples on age and ancestry were estimated by Mann-Whitney tests. The individual proportions of European, African and Amerindian genetic ancestry were estimated using the STRUCTURE software 2.3.3 assuming three parental populations (Europeans, Africans and Amerindians), and running with 200,000 burn-in period and 200,000 Markov Chain Monte Carlo repetitions after burning [18]. Poisson regressions were performed to assess the association between polymorphisms or haplotypes and age. The association between malaria cases and controls was performed using the STRAT software with 10,000 simulations [19]. STRAT utilizes the STRUCTURE output to test for association in the presence of population stratification based on individual ancestry information. MannWhitney, Qui-square and Poisson Regression tests were performed using the SPSS18.0 statistical package for Windows ${ }^{\circledR}$. Statistical significance was defined as a twotailed P-value $<0.05$.

\section{Results}

The 33 SNPs investigated, their location in the gene and the allele frequencies observed in malaria cases and controls are shown in Additional file 1. The genotype distribution did not deviate significantly from Hardy-Weinberg equilibrium in both samples (Additional file 2).

Age and mean ancestry proportions of the subjects enrolled in the study are shown in Table 1 . The control group was younger (32.8 \pm 16.5 years) and presented a larger proportion of European ancestry $(0.436 \pm 0.13)$ 
Table 1 Age and genetic ancestry of malaria and control subjects

\begin{tabular}{|c|c|c|c|}
\hline Characteristics & Controls & Malaria & $\mathrm{P}$ value ${ }^{\mathrm{a}}$ \\
\hline $\mathrm{N}$ & 263 & 216 & \\
\hline Age (y) & $32.8 \pm 16.5$ & $35.4 \pm 15.3$ & 0.003 \\
\hline \multicolumn{4}{|l|}{ Genetic Ancestry } \\
\hline African & $0.245 \pm 0.10$ & $0.246 \pm 0.09$ & 0.6 \\
\hline European & $0.436 \pm 0.13$ & $0.412 \pm 0.11$ & 0.03 \\
\hline Native American & $0.319 \pm 0.11$ & $0.342 \pm 0.12$ & 0.06 \\
\hline
\end{tabular}

than the malaria patients ( $35.4 \pm 15.3$ years; $0.412 \pm 0.11$ respectively). These differences were statistically significant between groups $(\mathrm{p}=0.003$ and $\mathrm{p}=0.037$, respectively). Due to this significant difference in age, a Poisson regression analysis using age as a covariate was performed. Only the polymorphisms with $\mathrm{P}<0.20$ between malaria and control samples were chosen for further analyses (Additional file 3).

Because ancestry proportions differ between malaria patients and controls (Table 1), the association between 13 SNPs, chosen from the Poisson regression analyses, was performed using the STRAT software (Table 2). After population structure correction, only IL1B -5839C $>\mathrm{T}$ and $I L 4 R$ 1902A $>$ G polymorphisms were associated with malaria susceptibility. The $I L 1 B-5839 \mathrm{C}$ and $I L 4 R$ $1902 \mathrm{~A}$ alleles are $8.2 \%$ and $6.2 \%$ respectively more frequent in malaria patients than in controls. Haplotype association tests adjusted for population stratification by the STRAT software are shown in Table 3. IL12RB1 and TNF haplotypes were associated with malaria susceptibility. The IL12RB1AC (-1094/-641) haplotype is only present in the malaria sample whereas the TNF TATGG
(-1031/-863/-857/-308/-238) haplotype is $2.5 \%$ more frequent in individuals with malaria.

\section{Discussion}

In a gene-based association study with 18 candidate genes for malaria susceptibility using 33 SNPs as genetic markers, this study demonstrated that IL1B, IL4R, IL12RB1 and TNF genes were associated with susceptibility to $P$. vivax malaria in a population of Pará state, Brazil.

Cytokines are immunomodulatory proteins produced by a wide variety of cells, and with very complex activities. A functional cytokine network is a central element in the homeostasis of the immune response and its alteration may lead to an abnormal immune response. Hence, recent interest has focused upon genes regulating the cytokine expression; in particular on gene polymorphisms that may influence the levels of expression and therefore the overall immune response. Despite evidence demonstrating the importance of $I L 1 B, I L 4 R$, IL12RB1 and TNF genes in P. falciparum malaria pathology, the influence of these variants in $P$. vivax infections is unknown.

Independent studies reported differences in immune system gene polymorphisms frequencies in distinct malaria-endemic regions [20]. The relevance of these polymorphisms in malaria infections could differ between distinct genetic background populations or etiologic agents, highlighting the importance of studies in different endemic regions. Due to the high admixed nature of the Brazilian population and its substructuring consequences in genetic association studies, this study dealt with this issue with extreme care. The population from Pará state has European, African and Amerindian ancestral groups $[16,21]$, so that a structured population

Table 2 Structured population association test between malaria and control samples

\begin{tabular}{|c|c|c|c|c|c|c|c|}
\hline \multirow[t]{2}{*}{ Gene } & \multirow[t]{2}{*}{ SNP } & \multirow[t]{2}{*}{ dbSNP ID } & \multirow[t]{2}{*}{ Allele } & \multicolumn{2}{|c|}{ Frequency (\%) } & \multirow[t]{2}{*}{$\mathrm{P}_{\mathrm{Qui}}^{2}$} & \multirow[t]{2}{*}{$P_{\text {Stra }}$} \\
\hline & & & & Control & $\overline{\text { Malaria }}$ & & \\
\hline$I L 1 B$ & $-5839 C>T$ & rs1143629 & $C$ & 46.2 & 54.4 & 0.01 & 0.04 \\
\hline ILAR & $1902 A>G$ & rs1801275 & A & 32.5 & 38.7 & 0.04 & 0.02 \\
\hline$\overline{I L 6}$ & $-174 C>G$ & rs1800795 & $C$ & 20.9 & 17.8 & 0.25 & 0.50 \\
\hline IL10 & $-592 A>C$ & rs1800872 & $A$ & 34.2 & 37.7 & 0.27 & 0.40 \\
\hline$I L 12 B$ & $458 \mathrm{~A}>\mathrm{G}$ & rs2546890 & A & 40.1 & 33.6 & 0.04 & 0.12 \\
\hline \multirow[t]{2}{*}{ IL12RBI } & $-1094 A>G$ & rs375947 & $G$ & 23.4 & 20.9 & 0.36 & 0.19 \\
\hline & $-641 C>T$ & rs11575934 & $G$ & 20.8 & 19.9 & 0.72 & 0.79 \\
\hline SP110 & $14622 C>T$ & rs2114592 & $T$ & 8.2 & 9.3 & 0.55 & 0.75 \\
\hline \multirow[t]{3}{*}{ TNF } & $-1031 C>T$ & rs1799964 & C & 24.0 & 21.9 & 0.44 & 0.10 \\
\hline & $-238 A>G$ & rs361525 & $A$ & 7.4 & 6.1 & 0.44 & 0.37 \\
\hline & $-857 \mathrm{C}>\mathrm{T}$ & rs1799724 & $T$ & 14.4 & 15.0 & 0.79 & 0.12 \\
\hline IFNG & $874 \mathrm{~A}>\mathrm{T}$ & rs2430561 & A & 25.8 & 28.3 & 0.38 & 0.29 \\
\hline IFNGRI & $-56 \mathrm{~T}>\mathrm{C}$ & rs2234711 & $C$ & 39.8 & 38.1 & 0.59 & 0.71 \\
\hline
\end{tabular}


Table 3 Structured population association test for haplotypes association between malaria and control samples

\begin{tabular}{|c|c|c|c|c|c|c|}
\hline \multirow[t]{2}{*}{ Gene } & \multirow[t]{2}{*}{ Haplotype } & \multirow[t]{2}{*}{ Allele } & \multicolumn{2}{|c|}{ Frequency (\%) } & \multirow[t]{2}{*}{$P_{\text {Qui }}^{2}$} & \multirow[t]{2}{*}{$P_{\text {Strat }}$} \\
\hline & & & Control & Malaria & & \\
\hline \multirow[t]{6}{*}{ ILIB } & $-5839 /-31 /-511$ & TTG & 49.0 & 42.8 & 0.02 & 0.07 \\
\hline & & TTA & 0.2 & 0.2 & & \\
\hline & & TCG & 2.9 & 0.9 & & \\
\hline & & TCA & 1.5 & 1.6 & & \\
\hline & & CTG & 0.2 & 1.5 & & \\
\hline & & CCA & 46.2 & 53.0 & & \\
\hline \multirow[t]{5}{*}{ IL10 } & $-592 \mathrm{~A} /-819 /-1082$ & CCA & 36.3 & 39.3 & 0.17 & 0.57 \\
\hline & & CCG & 29.2 & 22.8 & & \\
\hline & & CTA & 0.4 & 0.2 & & \\
\hline & & ATA & 34.1 & 37.5 & & \\
\hline & & ATG & 0 & 0.2 & & \\
\hline \multirow[t]{8}{*}{ IL12B } & 159/458/735 & CGC & 31.8 & 36.3 & 0.09 & 0.22 \\
\hline & & CGT & 1.4 & 4.0 & & \\
\hline & & CAC & 0.7 & 0.2 & & \\
\hline & & CAT & 2.7 & 2.4 & & \\
\hline & & AGC & 11.6 & 10.1 & & \\
\hline & & AGT & 14.1 & 15.8 & & \\
\hline & & AAC & 0.2 & 0.5 & & \\
\hline & & AAT & 37.5 & 30.7 & & \\
\hline \multirow[t]{4}{*}{ IL12RB1 } & $-1094 /-641$ & AT & 76.7 & 77.8 & 0.04 & 0.01 \\
\hline & & $A C$ & 0 & 1.4 & & \\
\hline & & GT & 2.5 & 2.3 & & \\
\hline & & GC & 20.8 & 18.5 & & \\
\hline \multirow[t]{14}{*}{ TNF } & $\begin{array}{l}-1031 /-863 /-857 / \\
-308 /-238\end{array}$ & TCCGG & 57.8 & 61.4 & & \\
\hline & & TCCGA & 1.6 & 0.2 & & \\
\hline & & TCCAG & 6.6 & 6.7 & & \\
\hline & & TCTGG & 11.1 & 9.8 & & \\
\hline & & TCTGA & 0.5 & 0.2 & & \\
\hline & & TCTAG & 0 & 0.2 & & \\
\hline & & TACGG & 1.3 & 0.2 & 0.07 & 0.01 \\
\hline & & TATGG & 1.3 & 3.8 & & \\
\hline & & CCCGG & 1.6 & 0.2 & & \\
\hline & & CCCGA & 0.5 & 1.0 & & \\
\hline & & CCTGG & 0.8 & 0.2 & & \\
\hline & & CACAA & 16.3 & 15.7 & & \\
\hline & & CACGA & 0.3 & 0.2 & & \\
\hline & & CATGG & 0.3 & 0.2 & & \\
\hline \multirow[t]{4}{*}{ IFNGR1 } & $-56 / 611$ & TA & 32.7 & 36.1 & 0.28 & 0.57 \\
\hline & & TG & 28.1 & 25.9 & & \\
\hline & & $C A$ & 38.0 & 37.7 & & \\
\hline & & $C G$ & 1.2 & 0.3 & & \\
\hline
\end{tabular}

association test to avoid genetic bias in the analysis was employed to provide reliable results for this specific population.

The IL-1 $\beta$, IL-12 and the TNF together with IFN- $\gamma$ are the major cytokines in pro-inflammatory Th1 immune response. IL-1 $\beta$ is predominantly secreted by monocytes and macrophages in initial immune response against infections [22-24] and helps to modulate the expression of IFN- $\gamma$ and promote the polarization to Th17 immune response in certain circumstances $[25,26]$. IL-12 promotes IFN- $\gamma$ production by $\mathrm{T}$ and natural killer (NK) cells and exerts its biological function through binding to the heteromeric interleukin 12 receptor (IL-12R) $\beta 1$ and $\beta 2$. The deficiency in IL-12R expression interferes in IL-12 functions and is associated with severe infection in humans $[27,28]$. TNF is produced by monocytes and macrophages and its role in malaria pathology was investigated due to reports of high levels of this cytokine in cerebral malaria patients [29].

$I L 1 B$ gene was associated with $P$. falciparum malaria in African populations only [30,31]. The present study is the first to report the association of $-5839 \mathrm{C}>\mathrm{T}$ SNP promoter with $P$. vivax malaria susceptibility. The $-5839 \mathrm{C}$ allele presented a higher frequency in malaria patients then in controls. Despite that, the function of this intronic SNP is not completely elucidated, variability of this important pro-inflammatory gene could represent an important factor in immune regulation. The association of haplotype $-31 \mathrm{C} /-511 \mathrm{~A}$ in $I L 1 B$ gene promoter with severe malarial anaemia and circulating IL-1 $\beta$ low levels in children with $P$. falciparum malaria from Kenya have been shown recently [32], however, the IL1B -31C $>\mathrm{T}$ polymorphism was not associated with cerebral malaria in Thailand [33]. In the present study these two SNPs were not associated with vivax malaria, demonstrating a possible difference in the contribution of these polymorphisms to malaria pathology among populations and parasites. Complementary studies in $I L 1 B$ gene and IL-1 $\beta$ levels are important to help understand how this gene influences malaria susceptibility and severity.

Recent work in Kenyan patients infected with P. falciparum demonstrated that IL12RB1 rs4229774 and rs383483 polymorphisms were associated with protection against severe malarial anaemia and high parasitaemia levels, but not susceptibility [34]. The present study reports the association of IL12RB1 -1094A/-641C haplotype with $P$. vivax malaria susceptibility. Despite the lower frequency in the study subjects, this haplotype is present only in the individuals with malaria, suggesting a possible influence in malaria response. The $-641 \mathrm{C}$ allele leads to a missense variant (i.e. encodes a different amino acid) and can modify the receptor properties and interfere with IL-12 ligation and function. These results suggest that IL12RB1 variants are important in malaria 
susceptibility and severity. Further studies will be necessary to better understand the IL12RB1 influence on susceptibility and severity in $P$. vivax malaria.

Polymorphisms in TNF gene promoter have been reported to be associated with symptoms and severity of P. falciparum malaria in different African and Asian populations [35-39]. The present work demonstrated that the TATGG $(-1031 /-863 /-857 /-308 /-238)$ TNF haplotype is associated with $P$. vivax malaria in a Brazilian population. TNF is an important pro-inflammatory cytokine and the TATGG haplotype diverge in two alleles $(-1031 \mathrm{C}$ and $-308 \mathrm{~A})$ associated with TNF levels in vivax malaria infection in India [12]. In that work it was hypothesized that $-1031 \mathrm{C}$ and $-308 \mathrm{~A}$ alleles are rare in Indian malaria patients due to a possible protective effect. The presence of $-1031 \mathrm{~T}$ and $-308 \mathrm{G}$ alleles in TATGG haplotype could be an important factor in vivax malaria susceptibility.

Interleukin 4 receptor (IL-4R), together with IL-4 and IL-13 are important Th2 anti-inflammatory immune response modulators. IL-4R is the principal receptor of these interleukins, and when it is blocked IL-4 and IL-13 function is aborted preventing Th2 immune response modulation [40]. Only a few works investigated IL-4R variants influence on malaria infections. In the present investigation an association of 1902A > G SNP with malaria susceptibility was observed. The $1902 \mathrm{G}$ allele create a missense variant and potentially can modify the receptor properties and interfere with IL-4 and IL-13 functions. It has been shown that the immune response via IL-4, IL4R and IL-13 pathway is important to prevent malaria infection in mice $[41,42]$. These studies demonstrated that knockout mice for IL4 and IL $4 R$ genes have high resistance to malaria liver stage caused by sporozoites. The absence of modulation mediated by IL- 4 to Th2 immune response, the Th1 response mediated by IFN $-\gamma$ is maintained and promotes a rapid cellular response against sporozoites. The present study shows that 1902A allele is more frequent in malaria patients, although 1902 G presents a higher overall frequency in the study population, 1902A allele could influence the co-regulation between Th1 and Th2 immune response against malaria infections. New complementary studies will be necessary to elucidate the $I L 4 R$ gene importance in vivax malaria infection.

IL4, IL10, IL12B, IFNG and IFNGR1 genes polymorphisms were associated with symptoms and severity of $P$. falciparum malaria in studies from African and Asian populations [11]. In the present study, polymorphisms in these genes were not associated with susceptibility to malaria caused by $P$. vivax. Differences in malaria pathophysiology caused by these two species of parasites could be a possible explanation for the divergences reported. Plasmodium falciparum malaria presents a more acute form of infection reaching more than $50 \%$ of erythrocytes leading to cyto-adherence, organ damaged, severe malarial anaemia and cerebral malaria. Malaria caused by $P$. vivax is characterized by a long incubation period and milder initial symptoms. The parasite infects approximately 2 to $5 \%$ of erythrocytes, and can remain dormant in the liver as hypnozoites leading to subsequently relapses [43]. Studies have linked high levels of pro-inflammatory cytokines, such as TNF, IL-1 $\beta$, IL-6 and IFN- $\gamma$ in P. falciparum infections [44-47] and TNF, IL-1 $\beta$, IL-2, IL-4, IL-6, IL-8, IL-10 e IL-12 cytokines with $P$. vivax infections $[13,48-50]$. These differences in cytokine profile and gene polymorphisms should reflect a distinct dynamic between the regulatory pathway of proand anti-inflammatory cytokines in $P$. falciparum and $P$. vivax malaria response, pathology and outcome.

\section{Conclusions}

Knowledge of the relationships between genetics, susceptibility to and severity of malaria infections is essential to identify subjects at higher risk and to develop specific preventive measures. This study showed that genetic polymorphisms of some interleukins involved in the immune response to $P$. vivax infection influence susceptibility to malaria. The present findings reinforce and increase our understanding about the role of the immune system in malaria susceptibility. However, to expand knowledge about the actions of the immune system in the pathophysiology of vivax malaria it is necessary to conduct population-based longitudinal studies.

\section{Additional files}

Additional file 1: Table S1. List of SNPS investigated in the present study. List of SNPs investigated, their location in the gene, pubmed database SNP identification, manufacturer's assay identification and allele frequencies in case and control groups.

Additional file 2: Table S2. Control and malaria group genotypic frequencies. Genotypic frequencies of all SNPs in case and control groups.

Additional file 3: Table S3. Poisson Regression for association between malaria and control samples controlling for age. Poisson Regression results for association between malaria and control samples controlling for age.

\section{Abbreviations}

Th: T helper; SNP: Single nucleotide polymorphism; TNF: Tumour necrosis factor; IFN-Y: Interferon gamma; IL: Interleukin; Indels: Insertion/deletion; NK: Natural killer; IL-12R: Interleukin 12 receptor; IL-4R: Interleukin 4 receptor.

Competing interests

The authors declare that they have no competing interests.

\section{Authors' contributions}

VAS designed the research project, carried out the laboratory assays, and wrote the manuscript; MGC participated in the study design, planning and data collection, revised the manuscript for important intellectual content and approved the version to be published; MDOO participated in the study 
design, planning and data collection, performed the malaria diagnosis and revised the manuscript for important intellectual content and approved the version to be published; JMS participated in the study design, planning and data collection, performed the malaria diagnosis and revised the manuscript for important intellectual content and approved the version to be published; NPCS participated in the study design, planning and data collection, performed the malaria diagnosis and revised the manuscript for important intellectual content and approved the version to be published; AKCR participated in the study design, planning and data collection, revised the manuscript for important intellectual content and approved the version to be published; SMC-J participated in the study design, planning and performed the statistical analysis and approved the version to be published; SEBS genotyped the ancestry informative markers, revised the manuscript for important intellectual content, and approved the version to be published; $\mathrm{MHH}$ conceived the study, and participated in its design and coordination, analysed the data, and wrote the final version of the article. All authors read and approved the final manuscript.

\section{Acknowledgements}

The authors thank the financial support provided by Conselho Nacional de Desenvolvimento Científico e Tecnológico (CNPq, Brazil). The funders had no role in study design, data collection and analysis, decision to publish, or preparation of the manuscript.

\section{Author details}

'Departamento de Genética, Universidade Federal do Rio Grande do Sul, Porto Alegre, RS, Brazil. Laboratório de Genética Humana e Médica, Universidade Federal do Pará, Belém, Pará, Brazil. ²Laboratório de Microbiologia e Imunologia, Instituto de Ciências Biológicas, Universidade Federal do Pará, Belém, Pará, Brazil. ${ }^{4}$ Programa de Ensaios Clínicos em Malária, Instituto Evandro Chagas, Secretaria de Vigilância em Saúde, Ministério da Saúde, Ananindeua, Pará, Brazil. ${ }^{5}$ Departamento de Estatística, Universidade Federal do Rio Grande do Sul, Porto Alegre, RS, Brazil.

Received: 19 July 2012 Accepted: 4 December 2012

Published: 7 December 2012

\section{References}

1. WHO: World malaria report 2011. http://www.who.int/malaria/ world_malaria_report_2011/9789241564403_eng.pdf.

2. Price $\overline{R N}$, Tjitra E, Guerra CA, Yeung S, White NJ, Anstey NM: Vivax malaria: neglected and not benign. AmJTrop Med Hyg 2007, 77:79-87.

3. da Silva-Nunes M, Ferreira MU: Clinical spectrum of uncomplicated malaria in semi-immune Amazonians: beyond the "symptomatic" vs "asymptomatic" dichotomy. Mem Inst Oswaldo Cruz 2007, 102:341-347.

4. Hotez PJ, Bottazzi ME, Franco-Paredes C, Ault SK, Periago MR: The neglected tropical diseases of Latin America and the Caribbean: a review of disease burden and distribution and a roadmap for control and elimination. PLoS Negl Trop Dis 2008, 2:e300.

5. Park JW, Jun G, Yeom JS: Plasmodium vivax malaria: status in the republic of Korea following reemergence. Korean J Parasitol 2009, 47(Suppl):39-50.

6. Lacerda MV, Mourão MP, Alexandre MA, Siqueira AM, Magalhães BM, Martinez-Espinosa FE, Filho FS, Brasil P, Ventura AM, Tada MS, Couto VS, Silva AR, Silva RS, Alecrim MG: Understanding the clinical spectrum of complicated Plasmodium vivax malaria: a systematic review on the contributions of the Brazilian literature. Malar J 2012, 11:12.

7. Mueller I, Galinski MR, Baird JK, Carlton JM, Kochar DK, Alonso PL, del Portillo HA: Key gaps in the knowledge of Plasmodium vivax, a neglected human malaria parasite. Lancet Infect Dis 2009, 9:555-566.

8. Good MF, Xu H, Wykes M, Engwerda CR: Development and regulation of cell-mediated immune responses to the blood stages of malaria: implications for vaccine research. Annu Rev Immunol 2005, 23:69-99.

9. Riley EM, Wahl S, Perkins DJ, Schofield L: Regulating immunity to malaria. Parasite Immunol 2006, 28:35-49.

10. Langhorne J, Ndungu FM, Sponaas AM, Marsh K: Immunity to malaria: more questions than answers. Nat Immunol 2008, 9:725-732.

11. Driss A, Hibbert JM, Wilson NO, Iqbal SA, Adamkiewicz TV, Stiles JK: Genetic polymorphisms linked to susceptibility to malaria. Malar J 2011, 10:271.

12. Sohail M, Kaul A, Bali P, Raziuddin M, Singh MP, Singh OP, Dash AP, Adak T: Alleles $-308 \mathrm{~A}$ and $-1031 \mathrm{C}$ in the TNF-alpha gene promoter do not increase the risk but associated with circulating levels of TNF-alpha and clinical features of vivax malaria in Indian patients. Mol Immuno/ 2008, 45:1682-1692.

13. Medina TS, Costa SP, Oliveira MD, Ventura AM, Souza JM, Gomes TF, Vallinoto AC, Póvoa MM, Silva JS, Cunha MG: Increased interleukin-10 and interferon- $\gamma$ levels in plasmodium vivax malaria suggest a reciprocal regulation which is not altered by IL-10 gene promoter polymorphism. Malar J 2011, 10:264.

14. Manual de diagnóstico laboratorial da malária 2005. http://portal.saude.gov. br/portal/arquivos/pdf/manual_diagnostico_malaria.pdf.

15. Sambrook J, Fritsch EF, Maniatis T: Molecular cloning. A laboratory manual. 2nd edition. Cold Spring Harbor, New York: Cold Spring Harbor Laboratory Press; 1989.

16. Santos NP, Ribeiro-Rodrigues EM, Ribeiro-Dos-Santos AK, Pereira R, Gusmão L, Amorim A, Guerreiro JF, Zago MA, Matte C, Hutz MH, Santos SE: Assessing individual interethnic admixture and population substructure using a 48-insertion-deletion (INSEL) ancestry-informative marker (AIM) panel. Hum Mutat 2010, 31:184-190.

17. Stephens M, Donnelly P: A comparison of bayesian methods for haplotype reconstruction from population genotype data. Am J Hum Genet 2003, 73:1162-1169.

18. Pritchard JK, Stephens M, Donnelly P: Inference of population structure using multilocus genotype data. Genetics 2000, 155:945-959.

19. Pritchard JK, Stephens M, Rosenberg NA, Donnelly P: Association mapping in structured populations. Am J Hum Genet 2000, 67:170-181.

20. Gonzalez-Galarza FF, Christmas S, Middleton D, Jones AR: Allele frequency net: a database and online repository for immune gene frequencies in worldwide populations. Nucleic Acids Res 2011, 39:D913-D919.

21. Pena SD, Di Pietro G, Fuchshuber-Moraes M, Genro JP, Hutz MH, KehdyFde S, Kohlrausch F, Magno LA, Montenegro RC, Moraes MO, de Moraes ME, de Moraes MR, Ojopi EB, Perini JA, Racciopi C, Ribeiro-Dos-Santos AK, RiosSantos F, Romano-Silva MA, Sortica VA, Suarez-Kurtz G: The genomic ancestry of individuals from different geographical regions of Brazil is more uniform than expected. PLOS One 2011, 6:e17063.

22. Dinarello CA: Biologic basis for interleukin-1 in disease. Blood 1996, 87:2095-2147

23. Dinarello CA: IL-18: A TH1-inducing, pro inflammatory cytokine and new member of the IL-1 family. J Allergy Clin Immunol 1999, 103:11-24.

24. Dinarello CA: Immunological and inflammatory functions of the interleukin-1 family. Annu Rev Immunol 2009, 27:519-550.

25. Veldhoen M, Hocking RJ, Atkins CJ, Locksley RM, Stockinger B: TGFbeta in the context of an inflammatory cytokine milieu supports de novo differentiation of IL-17-producing T cells. Immunity 2006, 24:179-189.

26. Chung Y, Chang SH, Martinez GJ, Yang XO, Nurieva R, Kang HS, Ma L, Watowich SS, Jetten AM, Tian Q, Dong C: Critical regulation of early Th17 cell differentiation by interleukin-1 signaling. Immunity 2009, 30:576-587.

27. de Jong R, Altare F, Haagen IA, Elferink DG, Boer T, van Breda Vriesman PJ, Kabel PJ, Draaisma JM, van Dissel JT, Kroon FP, Casanova JL, Ottenhoff TH: Severe mycobacterial and Salmonella infections in interleukin-12 receptor-deficient patients. Science 1998, 280:1435-1438.

28. Trinchieri G: Interleukin-12: a cytokine produced by antigen-presenting cells with immunoregulatory functions in the generation of T-helper cells type 1 and cytotoxic lymphocytes. Blood 1994, 84:4008-4027.

29. Grau GE, Piguet PF, Vassalli P, Lambert PH: Tumor-necrosis factor and other cytokines in cerebral malaria: experimental and clinical data. Immunol Rev 1989, 112:49-70.

30. Gyan B, Goka B, Cvetkovic JT, Perlmann H, Lefvert AK, Akanmori B, TroyeBlomberg M: Polymorphisms in interleukin-1beta and interleukin-1 receptor antagonist genes and malaria in Ghanaian children. Scand J Immunol 2002, 56:619-622.

31. Walley AJ, Aucan C, Kwiatkowski D, Hill AV: Interleukin-1 gene cluster polymorphisms and susceptibility to clinical malaria in a Gambian case-control study. Eur J Hum Genet 2004, 12:132-138.

32. Ouma C, Davenport GC, Awandare GA, Keller CC, Were T, Otieno MF, Vulule JM, Martinson J, Ong'echa JM, Ferrell RE, Perkins DJ: Polymorphic variability in the interleukin (IL)-1beta promoter conditions susceptibility to severe malarial anemia and functional changes in IL-1 beta production. J Infect Dis 2008, 198:1219-1226.

33. Ohashi J, Naka I, Doi A, Patarapotikul J, Hananantachai H, Tangpukdee N, Looareesuwan S, Tokunaga K: A functional polymorphism in the IL1B gene promoter, IL1B $-31 \mathrm{C}>\mathrm{T}$, is not associated with cerebral malaria in Thailand. Malar J 2005, 4:38. 
34. Zhang L, Prather D, VandenEng J, Crawford S, Kariuki S, TerKuile F, Terlouw D, Nahlen B, Lal AA, Slutsker L, Udhayakumar V, Shi YP: Polymorphisms in genes of interleukin 12 and its receptors and their association with protection against severe malarial anaemia in children in western Kenya. Malar J 2010, 9:87.

35. McGuire W, Hill AV, Allsopp CE, Greenwood BM, Kwiatkowski D: Variation in the TNF-alpha promoter region associated with susceptibility to cerebral malaria. Nature 1994, 371:508-510.

36. McGuire W, Knight JC, Hill AV, Allsopp CE, Greenwood BM, Kwiatkowski D: Severe malarial anemia and cerebral malaria are associated with different tumor necrosis factor promoter alleles. J Infect Dis 1999, 179:287-290.

37. Sinha S, Mishra SK, Sharma S, Patibandla PK, Mallick PK, Sharma SK, Mohanty S, Pati SS, Mishra SK, Ramteke BK, Bhatt R, Joshi H, Dash AP, Ahuja RC, Awasthi S, Indian Genome Variation Consortium, Venkatesh V, Habib S: Polymorphisms of TNF-enhancer and gene for FcgammaRlla correlate with the severity of falciparum malaria in the ethnically diverse Indian population. Malar J 2008, 7:13.

38. Clark TG, Diakite M, Auburn S, Campino S, Fry AE, Green A, Richardson A Small K, Teo YY, Wilson J, Jallow M, Sisay-Joof F, Pinder M, Griffiths MJ, Peshu N, Williams TN, Marsh K, Molyneux ME, Taylor TE, Rockett KA, Kwiatkowski DP: Tumor necrosis factor and lymphotoxin-alpha polymorphisms and severe malaria in African populations. $J$ Infect Dis 2009, 199:569-575.

39. Kuesap J, Hirayama K, Kikuchi M, Ruangweerayut R, Na-Bangchang K: Study on association between genetic polymorphisms of haem oxygenase-1, tumour necrosis factor, cadmium exposure and malaria pathogenicity and severity. Malar J 2010, 9:260.

40. Hünig T, Lühder F, Elflein K, Gogishvili T, Fröhlich M, Guler R, Cutler A, Brombacher F: CD28 and IL-4: two heavyweights controlling the balance between immunity and inflammation. Med Microbiol Immunol 2010, 199:239-246.

41. Saeftel M, Krueger A, Arriens S, Heussler V, Racz P, Fleischer B, Brombacher F, Hoerauf A: Mice deficient in interleukin-4 (IL-4) or IL-4 receptor alpha have higher resistance to sporozoite infection with plasmodium berghei (ANKA) than do naive wild-type mice. Infect Immun 2004, 72:322-331.

42. Morrot A, Hafalla JC, Cockburn IA, Carvalho LH, Zavala F: IL-4 receptor expression on CD8+ T cells is required for the development of protective memory responses against liver stages of malaria parasites. $J$ Exp Med 2005, 202:551-560.

43. Garcia LS: Malaria. Clin Lab Med 2010, 30:93-129.

44. Day NP, Hien TT, Schollaardt T, Loc PP, Chuong LV, Chau T, Mai NT, Phu $\mathrm{NH}$, Sinh DX, White NJ, Ho M: The prognostic and pathophysiologic role of pro- and anti-inflammatory cytokines in severe malaria. J Infect Dis 1999, 180:1288-1297.

45. Lyke KE, Burges R, Cissoko Y, Sangare L, Dao M, Diarra I, Kone A, Harley R, Plowe $C V$, Doumbo OK, Sztein MB: Serum levels of the pro inflammatory cytokines interleukin-1 beta (IL-1 beta), IL-6, IL-8, IL-10, tumor necrosis factor alpha, and IL-12(p70) in Malian children with severe plasmodium falciparum malaria and matched uncomplicated malaria or healthy controls. Infect Immun 2004, 72:5630-5637.

46. Clark IA, Budd AC, Alleva LM, Cowden WB: Human malarial disease: a consequence of inflammatory cytokine release. Malar J 2006, 5:85.

47. Prakash D, Fesel C, Jain R, Cazenave PA, Mishra GC, Pied S: Clusters of cytokines determine malaria severity in Plasmodium falciparum-infected patients from endemic areas of central India. J Infect Dis 2006, 194:198-207.

48. Karunaweera ND, Carter R, Grau GE, Kwiatkowski D, Del Giudice G, Mendis $\mathrm{KN}$ : Tumour necrosis factor-dependent parasite-killing effects during paroxysms in non-immune Plasmodium vivax malaria patients. Clin Exp Immunol 1992, 88:499-505.

49. Karunaweera ND, Wijesekera SK, Wanasekera D, Mendis KN, Carter R: The paroxysm of plasmodium vivax malaria. Trends Parasitol 2003, 19:188-193.

50. Zeyrek FY, Kurcer MA, Zeyrek D, Simsek Z: Parasite density and serum cytokine levels in Plasmodium vivax malaria in Turkey. Parasite Immunol 2006, 28:201-207.

doi:10.1186/1475-2875-11-409

Cite this article as: Sortica et al:: ILIB, IL4R, IL12RB1 and TNF gene polymorphisms are associated with Plasmodium vivax malaria in Brazil. Malaria Journal 2012 11:409.

\section{Submit your next manuscript to BioMed Central and take full advantage of:}

- Convenient online submission

- Thorough peer review

- No space constraints or color figure charges

- Immediate publication on acceptance

- Inclusion in PubMed, CAS, Scopus and Google Scholar

- Research which is freely available for redistribution

Submit your manuscript at www.biomedcentral.com/submit 